\title{
ANALISIS PENANAMAN MODAL ASING DAN EKSPOR TERHADAP PRODUK DOMESTIK BRUTO SEKTOR INDUSTRI DI INDONESIA
}

\author{
Iqfina Harun ${ }^{1}$, Cut Putri Mellita Sari ${ }^{2}$, \\ ${ }^{a}$ Fakultas Ekonomi dan Bisnis Universitas Malikussaleh \\ 1 Corresponding author iqfinaharun.net2018@gmail.com \\ 2 cmellita0674@gmail.com
}

\begin{tabular}{ll}
\hline A R T I C L E I N F O R M A T I O N & A B S T R A C T \\
\hline Keywords: & - This study aims to determine the effect of foreign investment and \\
Gross Domestic Product, & exports on GDP in the industrial sector in Indonesia. The data used in \\
Foreign Investment, & this study are secondary data from 2010 to 2018. The data analysis \\
Export. & method used in this research is multiple linear regression analysis. The \\
& results show that foreign investment and exports have a positive and \\
& significant effect on the GDP of the Indonesian industrial sector.
\end{tabular}

\section{PENDAHULUAN}

Perekonomian di Indonesia dipengaruhi oleh berbagai sektor. Artinya, banyak sekali sektor yang berperan penting dalam menyumbang angka PDB. Sebelumnya terdapat 9 sektor, namun setelah mengalami perubahan klarifikasi kini menjadi 17 sektor. Berikut adalah 5 sektor penyumbang angka tertinggi untuk PDB, pada tahun 2018:

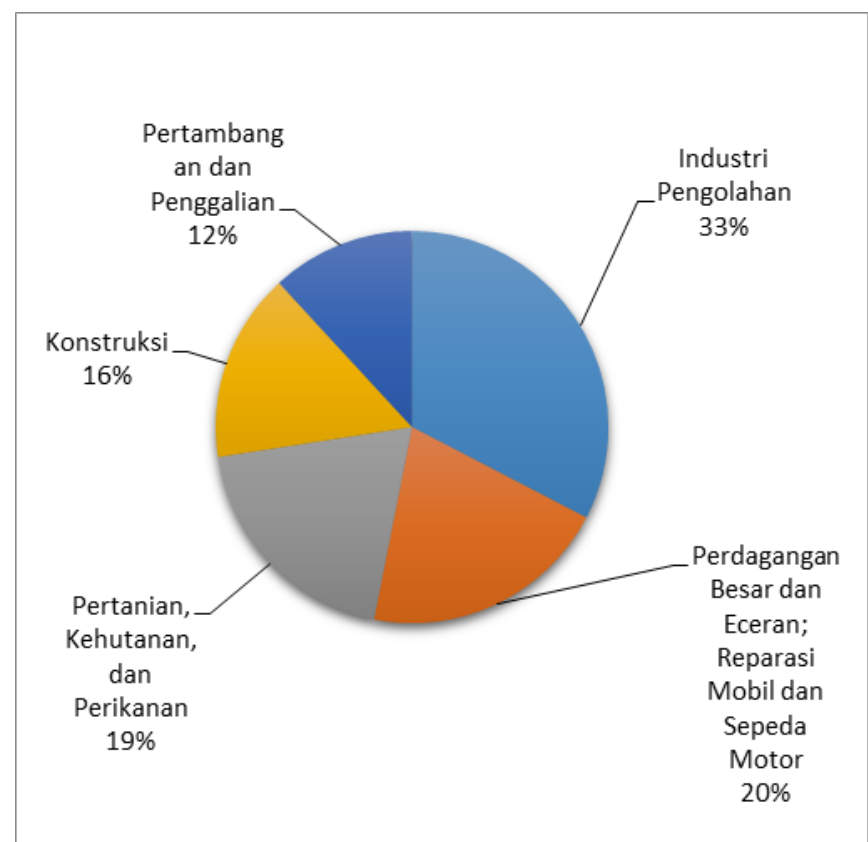

Sumber: Bps.go.id (Diolah, 2020)

Gambar 1

PDB Atas Dasar Harga Konstan 2010

Menurut Lapangan Usaha Tahun 2018 (Dalam Miliar Rupiah)
Berdasarkan Gambar 1.1, dapat dilihat bahwa dari 17 sektor yang ada, sektor di atas merupakan 5 sektor andalan yang sangat berkontribusi dalam menyumbangkan nilai PDB. Namun jika dibandingkan kembali, dari kelima sektor tersebut, sektor industri pengolahan merupakan sektor yang memberikan sumbangan terbesar bagi angka PDB.

Menurut teori Keynes, PDB terbentuk dari empat faktor yang secara positif mempengaruhinya, salah satunya adalah investasi (Mankiw, 2006) Investasi adalah modal yang diperoleh dari penanaman modal dalam negeri (PMDN) dan penanaman modal asing (PMA) yang dimanfaatkan untuk membeli peralatan modal dan barang produksi dengan tujuan untuk memproduksi output yang lebih efektif dan efisien di masa mendatang (Sukirno, 2000)(Sukirno, 2000a).

PMA membuka peluang bagi pengangguran untuk mendapatkan kesempatan kerja, karena dengan adanya investasi maka lapangan usaha yang tersedia akan semakin meningkat sehingga dampaknya dapat mengurangi tingkat pengangguran (Marwanti, 2017). Jika pengangguran berkurang maka masyarakat akan mampu memenuhi kehidupan hidupnya dengan mengandalkan pendapatan/upah yang dimiliki baik itu digunakan untuk konsumsi atau sebagai tabungan.

Meningkatnya konsumsi masyarakat secara agregat selanjutnya mampu meningkatkan PDB. Sebab secara langsung konsumsi juga merupakan salah satu penentu PDB suatu negara. 
Penanaman Modal Asing di Indonesia menjadi hal yang sangat diperhitungkan. Dari tahun ke tahun, PMA menyumbang nilai lebih tinggi dari pada PMDN.

Pada tahun 2017 dari total nilai investasi yakni Rp. 692,8 Triliun, PMA menyumbang angka sebesar Rp. 430,5 Triliun sementara PMDN adalah sebesar Rp. 262,3 Triliun. Artinya PMA memberikan nilai sebesar $62,1 \%$ bagi investasi di Indonesia, sementara PMDN adalah sebesar 37,9\%. Selanjutnya pada tahun 2018 kontribusi PMA bagi Investasi di Indonesia mengalami penurunan namun nilainya masih lebih besar daripada PMDN. Dari total nilai investasi Rp. 721,3 Triliun pada tahun 2018, PMA hanya menyumbang angka sebesar Rp. 392,7 Triliun $(54,4 \%)$ sedangkan PMDN yaitu Rp.328,6 Triliun (45,6\%). (BKPM, 2019).

Alasan Indonesia membutuhkan investor asing disebabkan oleh daya konsumsi masyarakat serta ekspor yang masih rendah. Infrastruktur kawasan industri dan sektor penunjang ekonomi tentu saja bisa menghabiskan anggaran yang besar. Untuk menarik minat investor asing, pemerintah Indonesia sudah mempersiapkan tempat dengan infrastruktur yang sesuai. Selain itu, pemerintah juga menyediakan beberapa fasilitas fiskal dan kemudahan perizinan yang berkaitan dengan kegiatan perusahaan.

Sebagai negara kepulauan terbesar, Indonesia mendapat sorotan dari dunia karena letaknya yang strategis. Namun, laju pembangunan cenderung lambat karena kurangnya modal dari investor dalam negeri. Maka dari itu, Indonesia membutuhkan penanaman modal asing untuk mendorong pembangunan serta kemajuan sektor industri dan pariwisata, hal ini akan berdampak pada pertumbuhan ekonomi yang diukur melalui PDB.

Untuk lebih jelasnya dapat dilihat dalam Tabel 1.1 mengenai perkembangan penanaman modal asing (PMA), ekspor dan produk domestik bruto sektor industri di Indonesia pada tahun 2014-2018, antara lain adalah sebagai berikut:

\section{Tabel 1}

Perkembangan PMA, Nilai Ekspor dan PDB

Tahun 2014-2018

\begin{tabular}{|c|c|c|c|}
\hline Tahun & $\begin{array}{c}\text { PMA } \\
\text { (Juta US\$) }\end{array}$ & $\begin{array}{c}\text { Nilai Ekspor } \\
\text { (Ribu US\$) }\end{array}$ & $\begin{array}{c}\text { PDB (Milyar } \\
\text { Rupiah) }\end{array}$ \\
\hline $\mathbf{2 0 1 4}$ & $28.529,70$ & 118.608 .410 & $1.854 .256,70$ \\
\hline $\mathbf{2 0 1 5}$ & $29.275,90$ & 106.188 .347 & $1.934 .533,20$ \\
\hline $\mathbf{2 0 1 6}$ & $28.964,10$ & 106.660 .895 & $2.016 .876,90$ \\
\hline $\mathbf{2 0 1 7}$ & $32.239,70$ & 122.131 .803 & $2.103 .466,10$ \\
\hline $\mathbf{2 0 1 8}$ & 29.308 .84 & 126.817 .901 & $2.193 .266,40$ \\
\hline
\end{tabular}

Sumber: bps.go.id, bi.go.id \& bkpm.go.id (2019)

Tabel 1.1 menujukkan bahwa ada tahun 2015, penanaman modal asing mengalami peningkatan yakni $28.529,70$ Juta US\$ pada tahun 2014 menjadi 29.275,90 Juta US\$ di tahun 2015. Berdasarkan teori yang menyatakan bahwa peningkatan PMA akan berdampak pada meningkatnya PDB. Jika dilihat dari data di atas maka kondisi ini sesuai dengan teori dimana PDB mengalami peningkatan di tahun 2015, yaitu dari Rp 1.854.256,70 Milyar menjadi Rp 1.934.533,20 Milyar pada tahun 2015. Namun pada tahun selanjutnya PMA berfluktuasi, ada kala mengalami peningkatan dan ada kala mengalami penurunan. Jika yang terjadi adalah peningkatan, maka hal tersebut kembali sesuai dengan teori yakni bisa dilihat dari nilai PDB yang mengalami peningkatan pada setiap tahunnya. Akan tetapi, pada tahun 2015-2016 serta tahun 2017-2018 nilai PMA mengalami penurunan.

Jika dikaitkan dengan teori, maka seharusnya penurunan PMA berdampak pada menurunnya PDB. Namun yang terjadi adalah sebaliknya yakni, PMA yang menurun justru meningkatkan nilai PDB. Hal ini berarti bahwa fenomena ini tidak sesuai dengan teori yang telah di uraikan di atas mengenai hubungan antara PMA dengan PDB, yang mana peningkatan PMA dapat meningkatkan PDB serta penurunan PMA akan menurunkan nilai PDB.

Selanjutnya dari segi ekspor, pada tahun 2015 ekspor mengalami penurunan dari tahun sebelumnya yakni 118.608.410 Ribu US\$ pada tahun 2014 menjadi 106.188.347 Ribu US\$ tahun 2015. Penurunan ini seharusnya ikut menurunkan nilai PDB. Namun yang terjadi, PDB tetap mengalami peningkatan meskipun ekspor mengalami penurunan yakni Rp.1.854.256,70 
Milyar pada tahun 2014 menjadi Rp.1.934.533,20 Milyar tahun 2015.

Maka dapat disimpulkan bahwa kondisi ini bertentangan dengan teori (Sukirno, 2006b) yang menyatakan bahwa ekspor adalah salah satu komponen pengeluaran agregat, oleh sebab itu ekspor dapat mempengaruhi tingkat produk domestik bruto yang akan dicapai. Artinya jika ekspor menurun maka PDB juga akan mengalami penurunan (Sukirno, 2006b).

Selanjutnya bagian kedua dari penelitian ini akan membahas tinjauan teoritis, metode penelitian akan dibahas pada bagian ketiga. Kemudian pada bagian ke empat akan dibahas hasil penelitian dan pembahasan. Pada bagian kelima akan membahas kesimpulan dan saran.

\section{KAJIAN TEORITIS}

\section{Produk Domestik Bruto}

PDB merupakan nilai barang atau jasa yang dihasilkan oleh faktor-faktor produksi dalam suatu negara baik milik warga negara yang bersangkutan dan negara asing, Artinya barang atau jasa yang dihasilkan tidak hanya perusahaan milik penduduk negara itu tetapi oleh penduduk negara lain selama masih ada kegiatan produksi di negara tersebut (Sukirno, 2012).

PDB adalah jumlah nilai seluruh barang dan jasa yang diproduksi oleh suatu negara dalam periode tertentu atau satu tahun termasuk barang dan jasa yang diproduksikan oleh perusahaan milik penduduk negara lain yang tinggal di negara bersangkutan (Latumaerissa, 2015).

(Pranoto, 2016) meneliti tentang pengaruh ekspor dan PDB Indonesia. Selanjutnya (Faiziah \& Sofyan, 2014) meneliti tentang pengaruh jumlah tenaga kerja, ekspor, investasi dan kredit perbankan sektor pertanian terhadap produk domestik regional bruto (PDRB) sektor pertanian Provinsi Aceh.

\section{PMA}

Penanaman modal asing sama dengan pemasukan modal dari luar yang bersumber dari luar negeri yang mengalir ke sektor swasta baik yang melalui investasi langsung (direct investment) maupun investasi tidak langsung (portofolio). Investasi langsung (Direct
Investment) dimana para investor bekerjasama dalam manajemen perusahaan untuk mendapatkan laba dari modal yang mereka tanamkan. Sementara Investasi Portofolio (Portofolio Investment), yakni membeli saham dan obligasi yang bertujuan untuk memiliki aset dari dana yang disimpan (Ulfa \& Andriyani, 2019).

Berdasarkan pendapat ahli serta beberapa uraian yang telah dijelaskan di atas dapat diambil kesimpulan bahwa PMA adalah penyimpanan modal yang dilakukan oleh para pemilik modal asing di dalam negeri dengan tujuan yaitu untuk mendapatkan keuntungan dari usaha yang dilakukan.

\section{Ekspor}

Perdagangan internasional terjadi apabila terjadi pertukan barang, jasa atau uang yang saling menguntungkan dan juga memberi manfaat yang didasarkan atas kesepakatan bersama. Ekspor merupakan penjualan barang dari dalam negeri ke luar peredaran Republik Indonesia dan barang yang dijual tersebut harus sesuai dengan ketentuan pemerintah yang berlaku, seperti dilaporkan kepada Direktorat Jenderal Bea dan Cukai Departemen Keuangan (Hamdani, 2012).

Ekspor diartikan pengeluaran barang dari masyarakat dan mengirim ke negara lain sesuai dengan pembayaran dalam bentuk valuta asing, dimana ekspor merupakan upaya melakukan penjualan komoditi yang di miliki oleh bangsa dan dijual kepada bangsa lain atau negara asing, dengan mengharapkan bayaran dengan valuta asing (Amir, 2005).

Berdasarkan uraian diatas maka dapat diambil kesimpulan bahwasannya ekspor adalah kegiatan menjual barang/jasa ke luar negeri dengan tujuan untuk mendapatkan keuntungan. Ekspor dapat terjadi jika ada kelebihan produksi, hal ini dikarenakan kelebihan produksi tersebut akan ditawarkan melalui kegiatan ekspor. 


\section{Kerangka Konseptual}

Berdasarkan landasan teoritis yang telah dikemukan di atas maka dapat disimpulkan kerangka konseptual pada gambar di bawah ini.

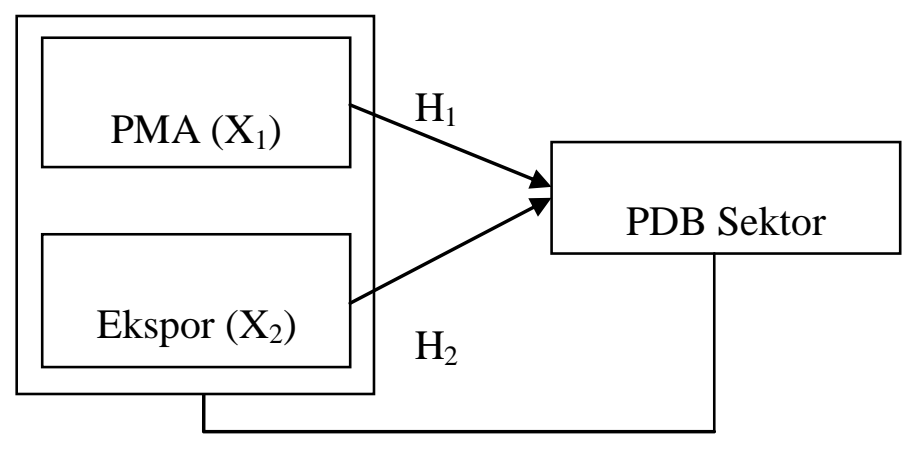

$\mathrm{H}_{3}$

\section{Gambar 2 Kerangka Konseptual}

Berdasarkan Gambar 2.1 di atas, kerangka konseptual dalam penelitian ini dapat dijelaskan, bahwa variabel PMA dan ekspor secara parsial berpengaruh signifikan terhadap PDB sektor industri dan secara simultan juga dapat diketahui bahwa variabel PMA dan ekspor berpengaruh signifikan terhadap PDB sektor industri.

\section{Hipotesis}

$\mathrm{H}_{1}$ : Diduga penanaman modal asing berpengaruh secara signifikan terhadap produk domestik bruto sektor industri di Indonesia.

$\mathrm{H}_{2}$ : Diduga ekspor berpengaruh secara signifikan terhadap produk domestik bruto sektor industri di Indonesia.

$\mathrm{H}_{3}$ : Diduga penanaman modal asing dan ekspor berpengaruh secara signifikan terhadap produk domestik bruto sektor industri di Indonesia.

\section{METODE PENELITIAN}

\section{Data dan Sumber Data}

Jenis dan data dalam penelitian ini adalah data sekunder berdasarkan runtun waktu (time series) tahun 2010 Q1 sampai dengan 2018 Q4. Sumber data dalam penelitian ini diperoleh dari laporan-laporan yang dipublish oleh Badan Pusat Statistik (BPS, 2019) dan Badan Koordinasi Penanaman Modal (BPS, 2019).
1. Produk domestik bruto (PDB). PDB yang dimaksud dalam peenelitian ini merupakan total nilai produksii barang dan jasa yang dihasiilkan oleh sektor industri pengolahan (Manufaktur) di Indonesia menurut lapangan usaha atas dasar harga konstan tahun 2010 yang bersumber dari Badan Pusat Statistik (BPS, 2019) dalam satuan Milyar Rupiah.

2. Penanaman modal asing (PMA). PMA yang dimaksud dalam penelitian ini adalah realisasi investasi Penanaman Modal Asing menurut sektor ekonomi yang diperoleh dari Badan Koordinasi Penanaman Modal (BKPM, 2019) dalam satuan juta US\$.

3. Ekspor. Ekspor yang dimaksud dalam penelitian ini merupakan nilai nominal ekspor komoditas industri (hasil manufaktur) yang diekspor oleh negara Indonesia, bersumber dari Badan Pusat Statistik (BPS, 2019) dalam satuan ribu US\$.

\section{Metode Analisis Data}

Metode analisis data yang digunakan dalam penelitian ini adalah penelitian kuantitatif maka untuk mengumpulkan data yang didapatkan dalam penelitian ini penulis menggunakan data sekunder. Untuk melihat pengaruh PMA dan ekspor terhadap PDB sektor indusri di Indonesia mengunakan model regresi linier berganda dengan bantuan program Eviews. Adapun persamaan model regresi linier berganda dalam penelitian ini adalah sebagai berikut:

$\angle O G P D B=$

$$
\beta_{0}+\beta_{1} \text { LOGPMA }+\beta_{2} \text { LOGEKSPOR }+e_{i}
$$

\section{HASIL DAN PEMBAHASAN Hasil Penelitian Hasil Uji Normalitas}

Menurut Ghozali (2011), pengujian normalitas dengan Jarque-Bera Test mempunyai chisquare dengan derajat bebas dua. Jika hasil Jarque-Bera Test $>$ nilai chi square pada $\alpha=$ $5 \%$, maka tolak $\mathrm{H}_{0}$ yang berarti tidak terdistribusi normal. Jika hasil Jarque-Bera Test $<$ chi square pada $\alpha=5 \%$, maka terima $\mathrm{H}_{0}$ yang berarti error term berdistribusi normal.

\section{Definisi Operasionalisasi Variabel}


Dari persamaan regresi di atas menunjukan bahwa nilai konstanta adalah sebesar 0.437 , artinya apabila variabel PMA dan ekspor dianggap konstan maka PDB adalah sebesar 0.437. Nilai koefisien dari variabel PMA adalah -0.003 , artinya apabila PMA meningkat satu persen dengan asumsi bahwa ekspor dianggap konstan, maka PDB akan menurun sebesar $0.003 \%$. Nilai koefisien dari variabel ekspor adalah 0.034, artinya apabila ekspor meningkat satu persen dengan asumsi bahwa PMA dianggap konstan, maka PDB akan meningkat sebesar $0.034 \%$.

\section{Uji Asumsi Klasik}

Sumber: Hasil Penelitian (Diolah, 2021)

Nilai $\mathrm{X}^{2}$ (Chi-Square) tabel dengan $\mathrm{df}=\mathrm{k}-$ $1(3-1=2)$, dan $a=5 \%$ adalah sebesar 5.99. Jiika dibandingkan dengan nilai J-B pada gambar di atas sebesar 1.43 maka nilai J-B $<$ nilai $\mathrm{X}^{2}$ (ChiSquare) tabel $(1.43<5.99)$. Selain itu berdasarkan hasil analisis di atas menunjukkan bahwa nilai probability adalah sebesar 0.49. Olieh kareana itu dapat disimpulkan bahwa penelitian ini telah terdistribusi normal karena nilai J-B < nilai $\mathrm{X}^{2}$ (Chi-Square) tabel $(1.43<$ 5.99) serta nilai prob $0.49>0,05$.

\section{Analiisis Regreisi Linier Bergaanda}

Untuk mengetahui hasil penelitian ini dapat dilihat dari output dengan menggunakan Eviews sebagai alat analisis. Hasil estimasi dilihat pada Tabel 3 berikut:

Tabel 3

Hasil Analisis Regresi Linier Berganda

\begin{tabular}{ccccc}
\hline \hline Variable & Coefficient & Std. Error & t-Statistic & Prob. \\
\hline \hline C & 0.437329 & 0.164012 & 2.666439 & 0.0132 \\
LOGPMA & -0.002546 & 0.012372 & -0.205777 & 0.8386 \\
LOGEKSPOR & 0.034307 & 0.015303 & 2.241931 & 0.0341 \\
LOGPDB(-1) & 0.192848 & 0.093241 & 2.068284 & 0.0491 \\
LOGPDB(-2) & -0.099941 & 0.104912 & -0.952616 & 0.3499 \\
LOGPDB(-3) & 0.032397 & 0.107940 & 0.300138 & 0.7666 \\
LOGPDB(-4) & 0.831061 & 0.099778 & 8.329096 & 0.0000 \\
\hline \hline & & & & \\
R-squared & 0.997392 & Mean dependent var & 13.06454 \\
Adjusted R-squared & 0.996766 & S.D. dependent var & 0.103689 \\
S.E. of regression & 0.005896 & Akaike info criterion & -7.238321 \\
Sum squared resid & 0.000869 & Schwarz criterion & -6.917691 \\
Log likelihood & 122.8131 & Hannan-Quinn criter. & -7.132041 \\
F-statistic & 1593.562 & Durbin-Watson stat & 1.618416 \\
Prob(F-statistic) & 0.000000 & & \\
\hline \hline
\end{tabular}

\section{Hasil Uji Multikolinieritas}

Menurut (Ghozali, 2006) untuk menguji ada tidaknya multikolinieritas dapat dilihat nilai koefisien korelasi antara masing-masing variabel bebas lebih kecil dari 0,8 yang berarti tidak terjadi multikolinieritas. Begitu juga sebaliknya apabila nilai koefisien korelasi antara masing-masing variabel bebas lebih besar dari 0,8 yang berarti terjadi multikolinieritas. Berikut ini merupakan hasil dari uji multikolinieritas:

\section{Hasil Uji Multikolinieritas}

\begin{tabular}{|c|c|c|}
\hline & LOGEKSPOR & LOGPMA \\
\hline LOGEKSPOR & 1.000000 & 0.225509 \\
\hline LOGPMA & 0.225509 & 1.000000 \\
\hline
\end{tabular}

Sumber: Hasil Penelitian (Diolah, 2021)

Tabel di atas menunjukkan bahwa nilai korelasi adalah sebesar $0.22 \quad(0.22<0.80)$. Berdasarkan hasil tersebut dapat disimpulkan bahwa semua variabel bebas yang digunakan dalam penelitian ini sudah terbebas dari uji multikolinieritas.

\section{Hasil Uji Autokoirelasi}

Pengujian terhadap autokorelasi dapat diuji dengan Metode Bruesch-Godfrey nama lain dari uji BG ini adalah LM test atau pengganda langrange. Apabila nilai Prob. Chi-Square $<\alpha=5 \%$ maka terdapat autokorelasi dan apabila nilai Prob. ChiSquare $>\alpha=5 \%$ maka tidak terdapat autokoorelasi (Ghozali, 2011).

Tabel 5

\section{Hail Uji Autokorelasi}

Breusch-Godfrey Serial Correlation LM Test:

$\begin{array}{llll}\text { F-statistic } & 0.462848 & \text { Prob. F(2,23) } & 0.6352 \\ \text { Obs*R-squared } & 1.238094 & \text { Prob. Chi-Square(2) } & 0.5385\end{array}$


Sumber: Hasil Penelitian (Diolah, 2021)

Berdasarkan table di atas dapat dilihat bahwa nilai Prob. Chi-Square(2) pada Obs*Rsquared adalah sebesar 0.5385 yang signifikan pada pada $\alpha=5 \%$. Oleh karena itu, dapat disimpulkan bahwa model ini terbebas dari uji autokorelasi atau tidak terjadinya autokorelasi karena nilai Prob. Chi-Square(2) $0.5385>0,05$.

\section{Hasil Uji Heteroskedastisitas}

Pengujian ini dapat diuji dengan metode White. Apabila nilai Prob. Chi-Square lebih besar dari tingkat keyakinan, maka tidak terindikasi heteroskedastisitas. Begitu juga sebaliknya apabila nilai Prob. Chi-Square lebih kecil dari tingkat keyakinan, maka terindikasi heteroskedastisitas (Ghozali, 2012).

\section{Tabel 6 Hasil Uji Heteroskedastisitas}

Heteroskedasticity Test: White

\begin{tabular}{llll} 
F-statistic & 1.116935 & Prob. F(6,25) & 0.3808 \\
Obs*R-squared & 6.764690 & Prob. Chi-Square(6) & 0.3432 \\
Scaled explained SS & 3.099758 & Prob. Chi-Square(6) & 0.7962 \\
\hline \hline
\end{tabular}

Sumber: Hasil Penelitian (Diolah, 2021)

Tabel 6 menunjukkan nilai Prob. ChiSquare(2) pada Obs*R-squared yaitu 0.3432 yang signifikan pada $\alpha=5 \%$. Maka dapat disimpulkan bahwa penelitian ini sudah terbebas dari uji heteroskedastisitas atau tidak terjadinya heteroskedastisitas, karena nilai Prob. ChiSquare(2) $0.3432>0,05$.

\section{Pengujian Hipotesis}

Uji t

Dari hasil pengujian pada tabel 3 dapat dilihat bahwa variabel PMA memiliki $t_{\text {hitung }}$ sebesar -0.206 dengan nilai probabilitas statistiknya sebesar 0.8386 dan nilai $\mathrm{t}_{\text {tabel }}$ dengan (df) $=\mathrm{n}-\mathrm{k}(32-3=29)$ pada $\alpha=0,05$ diperoleh nilai sebesar 2.04523. Jadi dapat disimpulkan bahwa $\mathrm{t}_{\text {hitung }}<\mathrm{t}_{\text {tabel }}$ yaitu $0.206<2.045(-0.206>$ -2.045), maka keputusannya adalah terima $\mathrm{H}_{0}$ dan tolak $\mathrm{H}_{1}$ artinya secara parsial PMA tidak berpengaruh secara signifikan terhadap PDB Sektor Industri di Indonesia.

Variabel ekspor memiliki $t_{\text {hitung }}$ sebesar 2.242 dengan nilai probabilitas statistiknya sebesar 0.0341 dan nilai $\mathrm{t}_{\text {tabel }}$ dengan $(\mathrm{df})=\mathrm{n}-\mathrm{k}$ $(32-3=29)$ pada $\alpha=0,05$ diperoleh nilai sebesar
2.04523. Jdi dapt disimpukan bahwa $t_{\text {hitung }}>t_{\text {tabel, }}$ yaitu $2.242>2.045$, maka keputusannya adalah tolak $\mathrm{H}_{0}$ dan terima $\mathrm{H}_{2}$ artinya secara parsial ekspor berpengaruh secara positif dan signifikan terhadap PDB Sektor Industri di Indonesia.

\section{Uji F}

Uji F dilakukan untuk mengetahui seberapa besar pengaruh variable bebas yaitu PMA dan ekspor secara serentak (bersama-sama) terhadap variabel dependen yaitu PDB Sektor Industri di Indonesia, dengan tingkat keyakinan 95\% $(\alpha=5 \%)$. Pengujian hipotesis dengan uji $\mathrm{F}$ dengan membandigkan antara $F_{\text {hiung }}$ dengan $F_{\text {tabel }}$.

Dari hasil pengujian di atas yang dapat dilihat pada Tabel 3 menunjukan bahwa variabel PMA dan ekspor memiliki $F_{\text {hitung }}$ sebesar 1593.562 dengan nilai probabilitas statistik sebesar 0.000000 dan nilai $\mathrm{F}_{\text {tabel }}$ dengan $(\mathrm{df})=\mathrm{n}-\mathrm{k}=32-3=29$ dan $\mathrm{k}$ $1=3-1=2$ pada $\alpha=0,05$ diperoleh nilai sebesar 3.33. Dapat disimpulkan bahwa $F_{\text {hitung }}>F_{\text {tabel }}$, yaitu $1593.562>3.33$, artinya secara serentak atau bersama-sama PMA dan ekspor berpengaruh secara psitif dan signfikan terhadap PDB Sektor Industri di Indonesia.

\section{Koefisien Determinasi $\left(\mathbf{R}^{\mathbf{2}}\right)$}

Untuk mengtahui pengaruh dari varibel indepeden terhadap dependen dapat diihat dari nilai $\mathrm{R}^{2}$. Dari hasil pengujian diperoleh nilai $\mathrm{R}^{2}$ sebesar 0.996766 yang berarti pengaruh dari variabel PMA dan ekspor tehadap PDB sektor Industri yaitu sebesar 0.996766 atau $99.6766 \%$, sementara sisanya yaitu 0.003234 atau $0.2324 \%$ dipengarUhi oleh varibel lain yang tidak dimasukkan dalam penlitian ini.

\section{Koefisien Koerelasi (R)}

Koefisien korelasi (R) digunakan untuk melihat keeretan hubungan yang terjadi antara variabel independen dengan variabel dependen. Berdasarkan pengujian pada tabel 4.5 maka apat diliat bahwa koefisen determinasi adalah sebesar 0.996766, maka untuk memperoleh nilai koefisien korelasi kita perlu mengakarkan nilai koefisien determinasi yaitu $\sqrt{0.996766}=0.998381$. Dari perolehan hasil tersebut, maka diketahui bahwa nilai koefisien korelasi adalah sebesar 0.998381, artinya hubungan antara PMA dan ekspor mmiliki hubugan yang sagat kuat terhdap PDB sektor Industri Indonesia yaitu sebesar $99.8381 \%$.

Berdasarkan hasil analisis regresi dijelaskan bahwa variabel PMA berpengaruh negatif dan tidak signifikan terhadap PDB di Indonesia. Hal ini 
disebabkan karena kondisi investasi di Indonesia sangat berfluktuatif.

\section{Pembahasan \\ Pengaruh PMA Terhadap PDB Sektor Industri}

Hasil penelitian menunjukan bahwa variabel PMA tidak berpengaruh secara signifikan terhaap PDB sektor industri Indonesia. Hasil ini tidak sesuai dengan hipotesis yang mana PMA berpengaruh secara positif dan sigifikan terhadap PDB sektor industri.

Penelitian ini memiliki hasil yang bertentangan denan teori yang menyatakan bahwa investasi (dalam hal ini yakni PMA) merupaan salah satu indiktor pembentuk PDB (Sukirno, 2000). Artinya jika PMA meningkat maka PDB juga ikut meningkat, demikian sebaliknya jika PMA menurun maka PDB juga akan menurun. Oleh karena itu, dapat disimpulkan bahwasannya secara teori, PMA memiliki hubungan yang positif terhadap PDB.

Berdasarkan hasil analisis regresi dijelaskan bahwa variabel PMA berpengaruh negatif dan tidak signifikan terhadap PDB di Indonesia. Hal ini disebabkan karena kondisi investasi di Indonesia sangat berfluktuatif. Indonesia belum menjadi prioritas sebagai tempat untuk menginvestasikan modal para investor luar negeri. Banyaknya hambatan masuk bagi investor asing, salah satunya adalah birokrasi yang kurang efisien dan berbelit-belit sehingga investor asing kurang berminat untuk menanamkan modalnya di Indonesia.

Meskipun bertentangan dengan teori yang ada, penelitian ini masih sejalan dengan penelitian terdahulu yang dilakukan oleh (Khair \& Bahrul, 2006) dengan judul Analisis pengaruh utang luar negeri (foreign debt) dan penanaman modal asing (PMA) terhadap nilai produk domestik bruto (PDB) Indonesia. Hasil penelitian tersebut membuktikan bahwa PMA tidak berpengaruh secara signifikan terhadap nilai PDB Indonesia.

Selanjutnya hasil penelitian ini juga sejalan dengan penelitian yang dilakukan oleh (Firdausi, 2013) dengan judul penelitian pengaruh infrastruktur, PMDN dan PMA terhadap produk domestik bruto di Indonesia yang memberi kesimpulan bahwa PMA tidak berpengaruh terhadap PDB di Indonesia.

\section{Pengaruh Ekspor Terhdap PDB \\ Sektor Industri Indonesia}

Hasil penelitian ini menunjukan bahwa ekspor berpengaruh secara poitif dan signifikan terhadap PDB sektor industri di Indonesia (Mankiw, 2006). asil penelitin ini sesuai dengan teori yang menyatakan bahwa ekspor adalah salah satu komponen pengeluaran agregat yang berpengaruh terhadap tingkat PDB yang akan dicapai. Jika ekspor meningkat maka PDB juga akan mengalami peningkatan. Sebaliknya jika Ekspor menurun maka PDB juga akan mengalami penurunan (Sukirno, 2006a).

Berdasarkan uraian di atas dapat disimpulkan bahwasannya secara teori, ekspor meiliki huungan yang posiitif terhadap PDB. Semakin besar nilai ekspor suatu negara akan meyebabkan semakin tinggi pula kegiatan ekonomi yang akan dicapai. Dengan adanya kegiatan ekspor di Indonesia, maka produsen akan menghasilkan barang/jasa yang melebihi jumlah produksi yang dibutuhkan di dalam negeri.

Kegiatan ekspor juga mampu menurunkan tingkat pengangguran, karena untuk memproduksi barang yang lebih besar maka perusahaan akan membutuhkan lebih banyak tenaga kerja. Oleh karenanya ekspor membuka peluang yang lebih besar dalam menyediakan kesempatan kerja.

Dengan berkurangnya tingkat pengangguran, maka masyarakat akan semakin sejahtera, mereka mampu memeuhi kebutuhan konsumsi yang lebih besar karena adanya pertambahan pendapatan yang mereka terima. Bertambahnya pendapatan maupun konsumsi masyarakat secara agregat akan berdampak pada peningkatan pertumuhan ekonomi di Indonesia.

Penelitian ini sejalan dengan penelitian terdahulu yang dilakukan (Pranoto, 2016) yang meneliti tentang pengaruh ekspor dan foreign direct investent terhadap pertumbuhan domestik bruto Indonesia. Hasil penelitian menunjukkan bahwa nilai ekspor berpengaruh secara positif dan signifikan terhadap PDB Indonesia.

Selanjutnya hasil penelitian ini sejalan dengan penelitian yang dilkukan oleh (Larasati \& Sulaimiyati, 2018) dengan judul penelitian pengaruh inflasi, ekspor dan tenaga kerja terhadap PDB, yang memberi kesimpulan bahwa variabel ekspor berpengaruh positif dan signifikan terhadap PDB.

\section{PENUTUP Kesipulan}

Berdasakan hasil penelitian maka penulis dapat mengambil beberapa kesimpulan diantaranya adalah sebagi beriut: 
1. Secara parsial (Uji t), penanaman modal asing tiak berpengaruh secara signifikan terhadap PDB sektor industri di Indonesia.

2. Seara parsial (Ui t), ekspor komoditas hasil industri manufaktur berpengaruh secara positif dan signifikan terhadap PDB sektor industri di Indonesia.

3. Secara simultan (Uji F), penanaan modal asing dan ekspor komoditas hasil industri berpengaruh secara positif dan signifikan terhaap PDB setor industri di Indonesia.

\section{Saran}

Berdasarkan uraian yang telah disampaikan pada sub bab sebelumnya, maka saran yang dapat diberikan dari hasil penelitian diantaranya:

1. Diharapkan bagi pemerintah maupun perusahaan yang berkaitan agar lebih memperhatikan hal-hal yang berhubungan atau yang berpengaruh terhadap PDB. Serta diharapkan agar pemerintah mampu membuat kebijakan-kebijakan yang mampu meningkatkan PDB.

2. PMA secara parsial tidak berpegaruh secara signifikan terhadap PDB, karena ada variabel lain yang mempengaruhi PDB. Pemerintah diharapkan mampu menciptakan stabilitas keamanan nasional sehingga para investor akan merasa aman dan tidak ragu untuk menanamkan modalnya di Indonesia. Oleh karena itu, PMA di Indonesia akan cenderung stabil dan tidak berfluktuasi.

3. Pemerintah sebaiknya membuat kebijakan meningkatkan ekspor yang menguntungkan eksportir dan negara, mempermudah eksportir dalam melakukan kegiatan ekspor barang, bahkan pemerintah bisa membantu pihak eksportir untuk memperoleh informasi yang dibutuhkan. Cara lain adalah meningkatkan kualitas barang dan jasa yang diekspor, menambah atau mengalihkan negara tujuan ekspor agar ekspor Indonesia meningkat.

4. Hail penelitian ini dapat menjadi acuan untuk penelitian selanjutnya, agar dapat melakukan perbaikan-perbaikan dan menambah variabel lainnya yang lebih berpengaruh terhadap PDB sekor industri di Indonesia.

\section{Daftar Pustaka}

Amir, M. S. (2005). Ekspor Impor Teori dan Penerapannya. PPM.

BKPM. (2019). bkpm.go.id (Diolah, 2020).
Statistik.go.id (diakses pada desember 2019). In Statistik Indonesia.

Faiziah, A., \& Sofyan. (2014). Pengaruh Jumlah Tenaga Kerja, Ekspor, Investasi dan Kredit Perbankan Sektor Pertanian Terhadap Produk Domestik Regional Bruto (PDRB) Sektor Pertanian Provinsi Aceh. Jurnal Agrisep, Vol. 15(2).

Firdausi, N. (2013). Pengaruh Infrastuktur, PMDN dan PMA terhadap Produk Domestik Bruto Di Indonesia. Economics Development Analysis Journalcs Development Analysis Journal, Vol. 2(4).

Ghozali, I. (2006). Aplikasi Analisis Multivariate Dengan SPSS (Cetakan Ke). Badan Penerbit Universitas Diponegoro.

Ghozali, I. (2011). Aplikasi Analisis Multivariate. Badan Penerbit Universitas Diponegoro.

Ghozali, I. (2012). Aplikasi Analisis Multivariate. Badan Penerbit Universitas Diponegoro.

Hamdani. (2012). Ekspor Impor Tingkat Dasar Level Satu. Bushido.

Khair, M., \& Bahrul, U. (2006). Analisis Pengaruh Utang Luar Negeri (Foreign Debt) dan Penanaman Modal Asing (PMA) Terhadap Nilai Produk Domestik Bruto (PDB) Indonesia. Jurnal Ecces, Vol. 3(!).

Larasati, I., \& Sulaimiyati, S. (2018). Pengarun Inflasi, Ekspor dan Tenaga Kerja Terhadap Produk Domestik Bruto (PDB). (Studi Pada Indonesia, Malaysia, Singapura dan Thailand). Jurnal Administrasi Bsnis (JAB), Vol. 61(1).

Latumaerissa, J. . (2015). Perekonomian Indonesia dan Dinamika Ekonomi Global. Mitra Wacana Media.

Mankiw, N. G. (2006). Teori Makro Ekonomi. Edisi Ketiga (Edisi Keti). Erlangga.

Marwanti, S. (2017). The Effects of Export , Import , and Investment on the Growth of the Indonesian Agricultural Sector. Jurnal Agro Ekonomi, 35(1), 49-65.

https://doi.org/http://dx.doi.org/10.21082/jae.v 35n1.2017.49-65

Pranoto, O. (2016). Pengaruh Ekspor dan Foreign Direct Investment Terhadap Pertumbuhan Domestik Bruto Indonesia. Jurnal Jibeka, Vol. 10(1).

Sukirno. (2000a). Pengantar Teori Mikro Ekonomi. PT. Raja Grafindo Persada.

BPS. (2019). Diunduh dari http.Badan Pusat 
Sukirno. (2006a). Ekonomi Pembangunan Proses

Masalah dan Dasar Kebijakan, cetakan

ketiga. Kencana.

Sukirno, S. (2000b). Mikro Ekonomi. Teori Pengantar. PT Raja Grafindo Persada.

Sukirno, S. (2006b). Ekonomi Pembangunan Proses Masalah dan Dasar Kebijakan, cetakan ketiga. Kencana.

Sukirno, S. (2012). Makro Ekonomi Teori Pengantar. PT Raja Grafindo Persada.

Ulfa, R., \& Andriyani, D. (2019). Analisis

Faktor-faktor yang mempengaruhi ekspor non migas Indonesia Tahun 1985-2017.

Jurnal Ekonomi Regional Unimal, 02, 1-2. 